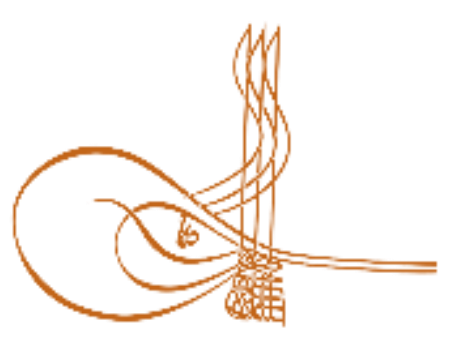

www.turkishstudies.net/turkishstudies
Turkish Studies

eISSN: $1308-2140$

Research Article / Araştırma Makalesi

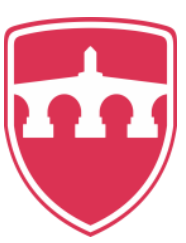

INTERNATIONAL

BALKAN

UNIVERSITY

Sponsored by IBU

\title{
Kişilik Özellikleri ve Kariyer Stresi İlişkisinde Örgütsel Güvenin Aracılık Etkisi Üzerine Bir Araştırma
}

\author{
A Study on the Mediating Effect of Organizational Trust in the Relationship Between Personality \\ Traits and Career Stress
}

\author{
Semra Köse ${ }^{* *}$ - Hasan Tutar ${ }^{* * *}$ - Nevzat Şahin ${ }^{* * * * *}$ - Sevilay Güler ${ }^{* * * * *}$
}

\begin{abstract}
It can be argued that there is an important share of personality traits in people's feelings, thoughts and all forms of perception. Although people have experienced the same situations, it can be assumed that they will react differently to these situations because they have different personality traits. The main purpose of this research is to determine whether organizational trust perceptions have a mediating effect on the relationship between people's personality traits and career stress. The general universe of the research consists of 465 healthcare professionals working in a hospital affiliated to the Ministry of Health in Istanbul. The research is cross-sectional and designed according to the quantitative research method. In collecting data; personality traits, organizational trust and career stress scales were used. In this correlational study, correlation and regression analyzes were performed from statistical analyzes to determine the relationships and effects between variables. In addition, Hayes Process macro was used to determine the significance of the mediation model, and the role of the mediator variable was tried to be determined between the dependent and independent variables. The results of the analysis revealed that organizational trust has a mediating role in the relationship between personality traits and career stress. In the "mediator effect analysis" conducted with Hayes Process,
\end{abstract}

\footnotetext{
* Bu çalışmadaki veriler 2019 y1lına aittir.

*** Dr. Öğr. Üyesi, İstanbul Aydın Üniversitesi, İşletme Fakültesi, İşletme Yönetimi

Asst. Prof. Dr., Istanbul Aydin Unlversity, Faculty of Business Management

ORCID 0000-0002-6993-5213

semrakose@aydin.edu.tr

**** Prof. Dr. Bolu Abant İzzet Baysal Üniversitesi, İletişim Fakültesi, Halkla İlişkiler Bölümü

Prof. Dr. Bolu Abant Izzet Baysal University, Department of Public Relation

ORCID 0000-0001-8383-1464

hasantutar@ibu.edu.tr

***** Doktora Öğrencisi, Sakarya Üniversitesi İşletme Enstitüsü

Phd Student, Sakarya University, Graduate School of Business

ORCID 0000-0002-6000-0833

nevzatsahin1453@gmail.com

****** Doktora Öğrencisi, Sakarya Üniversitesi İşletme Enstitüsü

Phd Student, Sakarya University, Graduate School of Business

ORCID 0000-0002-0913-4350

dsg_888@hotmail.com

Cite as/ Atıf: Köse, S., Tutar, H., Şahin, N., Güler, S. (2020). Kişilik özellikleri ve kariyer stresi ilişkisinde örgütsel güvenin aracıllk etkisi üzerine bir araştırma, Turkish Studies, 15(2), 1137-1154. https://dx.doi.org/10.29228/TurkishStudies.40441

Received/Geliş: 06 January/Ocak 2020

Accepted/Kabul: 25 April/Nisan 2020

Copyright $(\mathrm{C}$ MDE, Turkey

Checked by plagiarism software

Published/Yayın: 30 April/Nisan 2020

CC BY-NC 4.0
} 
the role of "organizational trust" in the relationship between "personality traits" and "career stress" has been put forward. Personality traits play an important role in providing organizational trust. In addition, the trust of employees in their organizations supports the perception that they will not be injured and reduces the level of career stress. Research findings show that personality traits are an important variable for organizations to achieve their goals.

\section{Structured Abstract:}

Introduction. Personality traits play an important role in people's emotions, thoughts and all kinds of perceptions. Although people have experienced the same situations, it can be said that they will react differently to these situations because they have different personality traits. The main purpose of this research is to determine whether the personality traits of people have a mediating effect on perceived career stresses and organizational trust perceptions. In the study, the question of whether personality traits have an organizational effect on career stress is also tried to be answered.

Method. The research is a correlational study determined by the quantitative research methodology. In the study, a model consisting of dependent, independent and mediator variables was tested. The data of the study were collected with personality traits, career stress and organizational trust scales and the data were analyzed by relationship and impact tests. The general universe of this cross-sectional study is 465 healthcare professionals working at the Istanbul Ministry of Health hospital. In the study, the relationships between variables and the effect of the argument on the dependent variable and the mediating variable were examined. Also, it is tried to be determined whether organizational trust functions as an mediator variable between independent and dependent variables as shown in the mediator model. In addition, hayes process macro was used to determine the importance of the mediation model and the role of the mediator variable between the dependent and the argument was tried to be determined.

Results. The results of the analysis showed that organizational trust has a mediating role in the relationship between personality traits and career stress. The results of the analysis revealed that there was a significant and positive relationship between personality traits and career stress and organizational trust. In the mediator effect analysis ile conducted with Hayes Process, organizational trust has a mediating role in the relationship between "personality traits" and "career stress". In this study, the fourth model of the PROCESS macro, developed by Andrew Hayes and based on SPSS, was used to test the mediator effect. Baron and Kenny (1986) stated that the first variable of the relationship that the mediator variable should have directly affects the mediator variable was analyzed within the scope of the model. The analysis results are given in Table 5. The results of the study revealed that personality traits had a significant and positive effect on the organizational trust perceptions of the participants.

The results of the analysis showed that the effect of organizational trust on the related variable was statistically significant $(\mathrm{p}<0.05)$. Organizational trust significantly and negatively affects career stress $(\beta=$ $.3858,95 \%$, LLCI-ULCI: -. 5590 / -. 2125). In addition, the results of the analysis revealed that personality traits had a significant effect on career stress $(\beta=.287,95 \%$, LLCI-ULCI: .1013 / .4720). It explains about $17 \%(\mathrm{R} 2=.1688)$ of the change in personality traits and career stress. The effect of the mediator variable on the independent variable in the model was examined within the framework of Baron and Kenny's (1986) model. The analyses showed that the personality trait variable had a direct and indirect effect on career stress through the mediating variable. While the direct effect reveals the effect of personality traits on career stress without the mediating variables, the indirect effect is expected to be statistically insignificant or diminish by adding the mediator variable to the analysis.

Discussion. Personality traits have an important role in providing organizational trust. However, the trust of employees in their organizations supports the perception that they will not be wronged and reduces the level of career stress. The findings of the study show that personality traits are an important variable in achieving the goals of the organizations. The results of the research show that there is a positive relationship between sub-dimensions of personality traits, extroversion, compliance, responsibility, emotional imbalance, and intelligence and imagination. The correlation analysis between the personality traits sub-dimensions and organizational trust showed that trust in management, trust in the organization and trust in the employees were related to all dimensions of the personality traits. As the level of trust of the employees' increases, the level of responsibility, compliance, extroversion increases and their tendency to share ideas that can benefit the organization through emotional balances increases. The fact that employees have extroverted, harmonious,

Turkish Studies, 15(2) 
responsible and open-minded personality traits affect their confidence levels positively and may lead to more positive behaviors.

When the literature is examined, there are empirical studies showing that personality traits affect organizational trust. If the individual has an introverted personality or prefers to spend time alone with others, this means that it will be more difficult for him/her to establish relationships and trust with others. Similarly, individuals with responsible personality characteristics are defined as employees sought by organizations and managers, while others are defined as individuals whom they want to be with and trust. Research has shown that responsible and extroverted individuals have successful interpersonal relationships and tend to trust, whereas neurotic individuals develop more difficult trust and are less likely to cooperate. Various research on the subject has shown that employees with high levels of compliance are more likely to believe that other individuals have good intentions and their trust levels are relatively high.

Keywords: Personality Traits, Career Stress, Organizational Trust, Mediating Effect.

Öz: Amaç: İnsanların duygularında, düşüncelerinde ve her tür algılama biçimlerinde kişilik özelliklerinin önemli bir payının olduğu ileri sürülebilir. İnsanların aynı durumları yaşamış olsalar da, söz konusu durumlara farklı kişilik özelliklerinde olmaları nedeniyle farklı tepkilerde bulunacakları varsayım olarak ileri sürülebilir. $\mathrm{Bu}$ araştırmanın temel amacı, insanların kişilik özellikleri ve kariyer stresi ilişkisinde, örgütsel güven algılarının aracı bir etkiye sahip olup olmadığını belirlemektir. Yöntem: Araştırmanın genel evrenini İstanbul'da Sağlık Bakanlığına bağlı bir hastanede görevli 465 sağlık çalışanı oluşturmaktadır. Araştırma kesitsel bir araştırmadır ve nicel araştırma yöntemine göre tasarlanmıştır. Verilerin toplanmasında; kişilik özellikleri, örgütsel güven ve kariyer stresi ölçeklerinden yararlanılmıştır. Korelasyonel bir araştırma olan bu çalışmada, değişkenler arası ilişkileri ve etkileri tespit etmek için istatistiksel analizlerden, korelasyon ve regresyon analizleri yapılmıştır. Ayrıca aracılık modelinin anlamlılığını belirlemek için Hayes Process makrosu kullanılmış, bağımlı ve bağımsız değişken arasında mediatör değişkenin rolü belirlenmeye çalışılmıştır. Bulgular: Analiz sonuçları kişilik özellikleri ve kariyer stresi ilişkisinde örgütsel güvenin aracı rolü olduğunu ortaya koymuştur. Hayes Process ile yapılan "mediatör etki analizi”nde "kişilik özellikleri” ve "kariyer stresi” ilişkisinde "örgütsel güvenin” aracı rolü ortaya konulmuştur. Sonuç: Kişilik özellikleri örgütsel güvenin sağlanmasında önemli bir role sahiptir. Bununla birlikte çalışanların örgütlerine güvenmeleri, haksızlığa uğramayacakları algısını desteklemekte ve kariyer stresi düzeyini düşürmektedir. Araştırma bulguları kişilik özelliklerinin örgütlerin amaçlarına ulaşmalarında önemli bir değişken olduğunu göstermektedir.

Anahtar Kelimeler: Kişilik Özellikleri, Kariyer Stresi, Örgütsel Güven, Mediatör Etki.

\section{Giriş}

İnsanın çalışma yaşamındaki öneminin anlaşılması, insana dair özelliklerin araştırılması gerekliliğini ortaya çıkarmıştır. Bu nedenle örgütsel verimlilik ve etkililik için bireylerin duygu, düşünce ve davranışlarının arkasındaki kişilik özelliklerini yansıtan ve onları diğerlerinden ayıran kişilik kavramının üzerinde durulması gerekmektedir. Birey çevresinde meydana gelen gelişmeleri izlemekte, değerlendirmekte ve kendine göre bir daranışta bulunmaktadır. Bireyin ortaya koyduğu davranışlardaki tutarlılığın ve farklılığın kaynağı onun kişiliğidir. Kişilik, bireyin tutarlı özelliklerinin tümüdür. $\mathrm{Bu}$ nedenle kişilik özelliklerinin belirlenmesi, örgütsel sorunların çözümlenmesi ve çalışanlar arası ilişkilerin düzenlenmesinde önem taşımaktadır (Robbins ve Judge, 2012:135). Kişilik özellikleri farklı olan insanların algılamaları farklılaştığı gibi bunların davranışsal düzlemdeki sonuçları da farklı olmaktadır.

İnsana dair tüm özellikler onu anlayabilmek konusunda bize ipuçları verir. Bireyin fiziksel görünümü, konuşma tarzı ve ses tonu, arzuları, heyecanları ve tepkileri onu diğer insanlardan farklı kılar. İnsanın bütün bu ayırıcı özellikleri onun kişiliğini meydana getirir. Kişilik, bireyin, kendine özgü sahip olduğu, onun diğerlerinden ayırt edilmesini sağlayan tüm özellikleridir. Bu ayırt edici özellikler bireyin psikolojik, zihinsel, fiziksel ve duygusal özelliklerinin bir yansıması şeklindedir. 
Bireyin iyimser veya kötümser olması, kendine güven düzeyi, sinirli olup olmaması, sıkılgan olması, kaygılı veya duygusal olması gibi özellikler onun özel ve çalışma hayatında önemli rol oynar (Tutar, 2015: 180-183). Bu bağlamda kişilik özelliklerinin hem bireyin kariyer stresi, hem de örgütsel güven düzeyiyle ilişkili olduğu ileri sürülebilir.

Çalışanların kişilik özelliklerini etkileyen önemli faktörlerden biri örgütsel güven düzeyleridir. Örgütsel güven, örgütteki ilişkileri birleştirici özelliğe sahiptir ve güven olmadan, örgütlerin amaçlarına ulaşabilmeleri kolay değildir (İşcan ve Sayın, 2010:195). Çalışanların örgüte, yöneticilere ve alışma arkadaşlarına inancı, güven duygularını etkilemektedir. Kaynakların eşit dağıtılacağı, süreçlerin hakkaniyet ölçütleri içerisinde sürdürüleceği, terfi, ücretlendirme, eğitim imkânlarından eşit şekilde yararlanılacağı ve haklarını korunacağı konusundaki inancı, örgütsel güveni etkilemektedir. Kariyer imkânlarından faydalanma konusunda temel yaklaşımın liyakat ve adalet çerçevesinde gerçekleşecek olması, çalışanların güven duygusunu pekiştireceği gibi kariyer stresini de azaltıcı rol oynayabileceği ileri sürülebilir. Bu çerçevede bu araştırmada kişilik özellikleri ve kariyer stresi ilişkisinin örgütsel güven aracılığıyla incelenmesi amaçlanmıştır.

Araştırmanın bağımlı değişkeni olan stres, içinde bulunulan psikolojik duruma uyumun getirdiği zorluğa bireyin verdiği tepkidir. Özellikle değişimin hızlı yaşanması sebebiyle insanların sürekli bir şeyleri kaçırıyormuş korku ve kaygısıyla hareket etmeye mecbur hissetmeleri stresi gündelik yaşamın bir parçası haline getirmektedir. Stres bugün aşırı değişimin getirdiği baskının ve yaşam döngüsündeki hızın artışından kaynaklanmaktadır. Geleneksel dönemlerde yaşam ve yaşama ait değerlerin dinginlikle karşılanması insanları gerilimden uzak tutmaktaydı oysa modern insanın bağlanma duygusu, gerçeği saptama şekli, kısaca herşey geçiciliğe mahkûm olmuş durumdadır. İnsanın iş ve sosyal çevresinde artan değişim ve karmaşaya bireylerin uyum sağlama yetenekleri önemli ölçüde zayıflamaya başlamıştır. Yaşanan bu yorgunluk ve bitkinlikle birlikte anlamsızlık, yalnızlık ve izole edilmişlik duygusu modern insana güvenden yoksun, gelecek korkusu içinde stres altında bir yaşam sürmesine neden olmaktadır.

Örgütsel güven, çalışanların kurumlarının uygulamalarına ve yöneticilerinin söz ve eylemlerine duydukları emin olma durumudur. Bilişsel ve duygusal olarak emin olma inancı güvenin temelini oluşturur. Bilişsel güven, söylenen sözlerin doğruluğundan, duygusal güven yöneticilerin iyi niyetli olduğundan emin olma durumuyla ilgilidir. Bir kişinin, başka birinin söz ve eylemlerine yüklediği eminlik düzeyine güven denilmektedir. Güven insanları psikolojik olarak bir arada tutar ve onlarda emniyet duygusu verir. Bilişsel güven kaynağını, güvenilecek tarafla ilgili bireyin sahip olduğu bilgiden alırken, duygusal güven, güvenilen kişiyle gönül bağıyla kurulan olumlu duygusal yakınlıktan alır (Tutar, 2016a: 296). Örgütsel güven kısa vadede oluşmayan fakat örgütsel başarı için gerekli bir duygudur. Örgütte çalışanlar tarafından paylaşılan değerler, inançlar ve vizyon yaratmak örgütsel güven aracılığıyla gerçekleştirilebilir. Çalışanların yöneticilerine ve örgütlerine güven duymaları, örgütlerde güvene dayalı ilişkilerin kurulması, örgütleriyle duygusal bağı olan, iş tatmini yüksek ve işten ayrılma niyeti olmayan çalışanlar, örgütsel güven sayesinde yaratılabilir.

Kişiliğin insanı diğerlerinden farklı kılan özellikler bütünü olması sebebiyle kişilik kavramını tanımlamak için psikoanalitik, davranışçılık, sosyal öğrenme, özellikler yaklaşımı olmak üzere farklı kişilik kuramları geliştirilmiştir. Bu çalışmada kişilik kavramı, özellikler kuramı çerçevesinde analiz edilmeye çalışllmıştır. Özellikler yaklaşımına göre, bireyin doğuştan var olan ve sonradan edindiği özellikler bütünü olan kişilik, Antonioni (1998:336) tarafından Beş Faktörlü Kişilik özellikleri olarak ele alınmıştır. Beş faktörlü kişilik yaklaşımı, kişilik özelliklerini çift kutuplu olarak incelemektedir. Bunlar; dişa dönüklük-içe dönüklük, geçimlilik-geçimsizlik, sorumluluksorumsuzluk, açıklık-kapalılık ve duygusal dengesizlik-duygusal tutarlılıktır (Antonioni, 1998:336). Bütün bu özelliklerin kişilerin stres düzeyleri ve güven algıları ile ilişkili olacağı ileri sürülebilir. 


\section{Kişilik Özellikleri}

Kişilik, bireyin tutarlı davranışlanıyla kazandığı kendine özgü yapısıdır. Kişilik, zamanın insanlara yüklediği biyolojik ve sosyal özellikler ve bu özelliklerin belirli bir süre sürekliliğini muhafaza eden davranışlar, duygular, düşünceler ve eylemler bütünüdür (Hellriegel vd. 1989: 37). Tanımda ifade edildiği üzere kişilik bireyi öznel ve nesnel yanlarıyla diğerlerinden ayıran duygu, düşünce, tutum ve davranış özelliklerinin tümüdür. Kişilik bir bireyin bütün tutumlarını, ilgilerini, yeteneklerini, dış görüşünü, konuşma tarzını, çevresiyle ilişkisini ve tüm özelliklerini içerir. Kişinin kısaca topyekün yaşam tarzı onun kişiliğini meydana getirir. Kişilik belirli bir durumda ya da belirli olaylar karşısında kişinin kendine has takındığı tavrın süreklilik gösteren dışsal yönüdür. Kişi tavrını takınırken, bir grup içerisinde diğerlerini nasıl etkilediği, kendini nasıl gördüğü ve diğerleri karşısında nasıl davrandığı onun kişiliği ile ilgilidir. Allport (1952:19) kişilik tanımlarını biyofiziksel ve biyososyal olarak iki kategoride incelemiştir. Bu çalışmada kişiliğin biyososyal kişilik özellikleri üzerinde durulmuştur. Bu özellik, bireyi sosyal uyaran olarak kabul etmektedir. Burada temel kişilik tanımlayıcısı, onun diğerleri üzerinde yarattığı ya da oluşturduğu etkidir. Biyofiziksel yapı ise kişiliğin somut ve görünen yanlarıyla ilgilidir.

Kişilik karakter, mizaç ve yetenek açısından değerlendirilir. Karakter, genel olarak kişilikle aynı anlamda kullanılmasına rağmen, kişiliğe ait sosyal ve ahlaki yönünü tanımlamaktadır. Karakter, bireyin zihinsel gücünü oluşturan ve şekillendiren özellikleridir. Bireyin içinde bulunduğu çevrenin toplumsal değerleri ve ahlaki kurallarıyla ilgilidir. Karakter, bireyin dahil olduğu çevre için geçerli değer yargıları ve ahlak kurallarına karşı takındığı tutum ve davranışıdır (Eroğlu, 2000:149). Kişiliği meydana getiren ikinci özellik olan mizaç (huy) ise, bireyi diğer bireylerden farklılığını oluşturan bazı temel özelliklerdir. Mizaç, kişiye özgü, oldukça sınırlı, belirli duygusal tepkilerin ortaya konuş şeklidir. Mizaç, algı ve tepki biçimleri, duyguların çabuk uyanıp uyanmaması, devamlı ve yoğun olup olmaması, derin duyulup duyulmaması ve kişisel özelliklerin tümü şeklinde açıklanabilir (Zel, 2001:28). Mizaç bireyin duygusallık yönünün ifadesidir. Mizaç neşeli, soğukkanlı, kızgın ya da melankolik olabilir (Zel, 2001:28). Kişiliği oluşturan diğer bir unsur yetenektir. Fiziksel yapıya benzer şekilde, zekâ ve yetenekler kişiliğin tanımlanmasında kullanılan özelliklerdir. Yetenek, toplumun bireye karşı davranışlarında belirleyicidir ve birey toplumun yönelişine karşı tepki ve davranışlarını belirler. Yetenek kişiliğin şekillenmesinde önemli bir faktördür ve yetenekler zihinsel ve bedensel olarak ikiye ayrılır. Fiziksel olarak ortaya çıkan yetenekler bedensel yeteneklerdir. Bunların çoğu bireyin doğuştan getirdiği ve zamanla kullanılabilir kıldığı özelliklerdir. Zihinsel yetenekler ise ilişkisel analiz, kavrayabilme, çözümleyebilme ve sonucu anlamlandırabilme tarzında analitik yetenekleri kapsamaktadır.

Yapılan kişilik tanımlarından ve kişiliği oluşturan unsurlardan yola çıkarak bireyin kişiliğini belirleyen özellikler şöyle sıralanabilir (Tutar 2016b:49):

- Kişilik doğuştan gelen eğilimler ile sonradan edinilen eğilimlerin toplamından meydana gelir,

- Kişilik, doğuşla gelen yetenekler ve sonradan kazanılan becerilerin düzenlenmesidir,

- Kişilik, davranışları yönlendirir ve idare eder,

- Kişilik, bireyin eğilimini içinde bulunduğu çevre ile uyumunu sağlar; birey sosyal uyum gereği, farklı çevresel şartlarda, farklı tutum ve davranış sergileyebilir.

- Her kişiliğin doğuştan gelen bir karakteri bulunmaktadır. Karakter, kişiliğin omurgasını oluşturur,

Bireyleri kendilerine özgü kılan ve onların kalıcı özelliklerini yansıtan kişilik, birden fazla faktöre bağlı olarak meydana gelmektedir. Kısaca sayılacak olursa bunlar; biyolojik ve kalıtsal faktörler, sosyo-kültürel faktörler, ailevi faktörler, sosyal yapı faktörleri ile sosyal sınıf faktörleri, 
coğrafi ve fiziki faktörler, iletişim hatta ailede doğum sırası gibi faktörlerdir. Beş faktörlü kişilik türlerinden dı̧̧a dönüklük (extroversion), toplum içinde olmayı seven, aktif, sosyal, konuşkan, heyecanlı, eğlenmeyi seven, iyimser, duygularını göstermekte rahat olan, risk alabilen, değişikliği tercih eden bireylerin kişilik özelliklerini ifade ederken, içe dönüklük; çekingen, mesafeli, ağır başlı, görev odaklı, utangaç ve sessiz olmakla ilişkilidir (Bowditch ve Buono 2005:46). Dişa dönük kişiler, dış dünyaya açıktır ve diğer bireylerle kolay iletişim kurabilirler. Ayrıca sosyal hareketlere ve gruplara öncüldürler. Bunun tam zıttı ise içe dönük tiplerdir. Iç̧e dönükler, iletişimde zorlanan, çevresinden soyutlanmış, arkadaşlık ilişki düzeyi düşük ve kendi dünyalarında var olan kişilerdir. Geçimlilik (agreeableness), iyi niyetli, temiz kalpli, yumuşak huylu, yardımsever, güvenilir, inatçı olmayan, hoşgörülü, merhametli, dürüst, kolay aldanan bireyleri ifade eden kişilik tipidir. Bunun tam zıttı olan geçimsizlik özelliğine sahip kişiler ise kaba, tahammülsüz, alaycı, şüpheci, kindar, benmerkezci, iş birliğine yatkın olmayan, agresif, merhametsiz ve dalavereci insanlardır (Mount vd. 1998:145). Sorumluluk (conscientiousness) bir işi tam yapan, durumdan vazife çıkaran, zamanı etkin kullanan kişileri ifade eden kişilik tipidir. Sorumluluk özelliklerine sahip bireyler işleri konusunda düzenli, duyarlı ve yüksek performans gösteren insanlardır. Sorumsuzluk özelliği baskın olan kişiler ise vurdumduymaz, amaçsız, güvenilmez, tembel, kararsız, düzensiz, dikkatsiz ve ihmalkâr özellikleri yüksek olan insanlardır. Açıklık (openness) ise, ilgi alanı geniş, öğrenme merakı yüksek, yaratıcı, analitik düşünen, girişimci, hayal gücü kuvvetli, orijinal ve yenilikçi bireyleri ifade eden kişilik tipidir. Kapalılık özellikleri baskın kişiler, gelenekçi, muhafazakâr, ilgi alanı dar, sanatsal zevkleri olmayan insanlardır (Tutar 2016b:61). Duygusal dengesizlik (neuroticism), duygularını kontrol edemeyen, içe kapanık ve aşırı karamsar, melankolik olmak ile aşırı neşeli, kaygısız özellikler gibi birbirine zit iki kutuplu (bipolar) duygu durumunu yaşayan bireylerin kişilik özellikleridir. Duygusal tutarlılık özelliği baskın olan kişiler özgüveni yüksek, rahat, sabırl, benlik saygısı gelişmiş ve kendinden memnun kişilerdir (Somer vd. 2002:24).

\section{Kariyer Stresi}

Stres, kişinin fiziksel ve sosyal çevreden gelen uyumsuz şartlar sebebiyle, bedensel ve psikolojik sınırlarının ötesinde harcadığı gayret olarak ifade edilmektedir (Cüceloğlu 1992:321). Daha genel bir ifade ile bireyin içinde bulunduğu ortam ve çalışma koşullarının, onu etkilemesi neticesinde, vücudunda özel biyo-kimyasal salgılar oluşarak, söz konusu şartlara uyum için bedensel ve düşünsel olarak, harekete geçmek için üzerinde hissettiği baskı durumuna stres denilmektedir (Eren 1998:224). Stres kişiye has ve onun bireysel bütünlüğünü zorlayıcı ve bozucu etkenlerdir (Baltaş ve Baltaş 1999:27). Fizyolojik ve psikolojik sebeplerden kaynaklanan ve sinir sistemini aşırı derecede yıpratarak, organizmada gerginlik, sıkıntı, yorgunluk, dikkat dağınıklığı, güvensizlik ve çöküntü şeklinde açığa çıkan psikolojik rahatsızlık durumuna stres denilmektedir. Stres bireyin tehdit edici içsel ve çevresel koşullara karşı gösterdiği tepkidir. Stres insanların kontrolü dışında gelişir ve bu kontrolsüzlük sebebiyle kişinin zihinsel ve psikolojik sağlığı olumsuz yönde etkilenir. Kaynağ1 her ne olursa olsun stres, çevresel bir talebe vücudun verdiği belirsiz bir reaksiyondur. Yapılan tanımlardan hareketle stresin özellikleri şöyle sıralanabilir:

- Stres, kişi ve çevrenin etkileşimi sonucunda meydana gelir.

- Stres, güdülenmiş durumdan daha güçlü bir şekilde insanı harekete geçirir.

- Streste tehlike söz konusudur ve bu tehlikenin önemi algılanmalıdır.

- Stres, organizmanın tamamını etkiler ve çoğu kez kontrol edilemez bir tepkidir.

Çalışma hayatı ve iş ortamı, strese neden olan faktörlerdendir. İş ortamları çıkar çatışmalarının yoğun olarak yaşandığı ortamlardır. İnsanın kişiliğine bağlı olarak oluşan farklı istek ve arzularının karşılanamaması ya da istek dışı görevlerin yerine getirilme mecburiyeti örgütleri stres ortamı haline getirmektedir. İster işleri, ister kariyerleriyle ilgili olsun kendi plan ve programlarını tasarladıkları gibi gerçekleştiremeyen ve dış koşullar sebebiyle onları değiştirmek zorunda kalan 
insanlar aşırı stres altında kalmaktadırlar. Kariyer, insanın iş yaşamı boyunca geçtiği aşamalar ve deneyimlerinin tümüdür. Kariyer insanlar için sahip oldukları yetenekler, çalışma ve bilgi edinme hevesiyle çalıştıkları kurumda terfi etmek anlamına gelmektedir (Turpçu ve Akyurt 2018:368). Kariyer genel olarak çalışılan iş kolunda dikey bir hareketliliği ifade eder.

Kişinin kariyeri keşfetme, kurma, kariyer ortası ve kariyer sonu aşamalarından oluşmaktadır. Keşfetme aşamasında (0-25 yaş), bireyin mesleki ilgileri sınırlı bilgileri çerçevesinde bir heves niteliğindedir. Birey bu aşamada meslekler içinde hangisinde daha başarılı olacağını belirlemekte, kendini tanımakta ve geliştirmektedir. Kurma aşamasında (26-35 yaş), birey işini bulmuş bir yetişkin olarak kabul edilmektedir. $\mathrm{Bu}$ aşamada kişi kendi işi ile ilgili yeni firsatları aramakta ve değerlendirmektedir. Orta kariyer aşamasında (36-55 yaş) ise, birey artık işinde iyice ustalaşmış, yeri sağlamlaşmış ve hiyerarşik olarak bir-iki basamak yükselmiş durumdadır. Bu aşamada birey için başarı ve saygınlık gibi ihtiyaçları önem kazanmıştır. Birey bir yandan yerini korurken, diğer yandan yükselme imkanlarını araştırır. Kariyer sonu aşamasında (56-75 yaş) ise kişi fiziksel olarak yaşlanmış ama büyük bir tecrübe birikimi kazanmıştır. Kişi bu dönemde konumu ile saygı görür ve fazla yükselme eğilimi göstermez. Kariyer bu aşamada durgunluk ve gerileme sürecine girer ve kariyer aşamalarında birey birçok stres unsuru ile karşılaşmaktadır.

Kurumlarda başarı değerleme standartlarının yetersizliği ve başarı değerlemede objektif olunmaması, terfi imkanlarının olmaması ya da terfide kayırmacı tutumlar birey için kariyer stresi faktörleridir. Yetersiz ya da hızlı terfi, terfide objektif davranılmayacağı endişesi, iş güvensizliği, hırs, başarı hevesinin engellenmesi gibi faktörler bilhassa başarı dürtüsü yüksek kişiler için önemli birer stres faktörüdür. Orta kariyer aşamasındaki kișiler kendilerinin aynı dönemdeyken aldıkları ücret ve imkanlardan fazlasını elde eden, hayatlarında oldukça esnek olan, sınırlandırıcı çalışma şartlarında çalışmayan ve aile sorumluluğu taşımayan kişilere karşı pek sıcak yaklaşmazlar ve hatta öfke duyabilirler. Öfkenin bastırılamaması stres düzeyini yükseltir; öfkeyi bastırmaya çalışmak ise örgütsel açıdan boşa harcanan enerji anlamına gelir. Kariyer ortası aşamasındaki bireyler için çalışma ortamı her geçen gün tehdit edici nitelik kazanır. İlerleme imkanlarının azalması aynı zamanda yeni ve çağdaş bilgilere sahip genç çalışanların kendilerini gösterme isteğiyle yaptıkları davranışlar kariyerinin orta aşamasında bulunan çalışanları hem eşitleriyle hem de astları konumundaki genç çalışanlarla yarışmaya mecbur bırakmaktadır. Özellikle yüksek rekabetin bulunduğu iş kollarında çalışanlar için her sene bir dönüm noktasıdır. Tüm bunların birey için anlamı, sürekli bir stres ve yenilgi korkusu altında yaşamak demektir.

\section{Örgütsel Güven}

Örgüte güven, çalışanların, belirsiz ve riskli bir durumla karşı karşıya kaldıklarında örgütün taahhütlerinin ve davranışlarının tutarlı olacağına ilişkin inançlarıdır. Örgütlerde yönetimin, yöneticinin ve diğer çalışanların tutum ve davranılarından emin olma durumudur. Örgütsel güven bireyin, örgütsel her tür karar ve eylemin kendi yararına olacağına dair inancıdır. Çalışanların, örgütün, kendi zararlarına herhangi bir karar almayacağına dair inancını ifade eder. Yönetimin çalışanlara destek olması, çalışanların arzu ve ihtiyaçlarının karşılanması, işyerindeki sosyal ilişkilerin istenilen düzeye çıkarılması, çalışanlar arası iş birliğinin geliştirilmesi bakımından önemlidir. Güven çalışanda tarafların beklenilen şekilde davranacaklarına ve beklentilerin karşılanacağına dair onda bir eminlik duygusu oluşturur. Verilen sözlerin yerine getirileceğine dair inanç hişinin, bir bakıma örgüte olan inancına dayalı teslimiyet duygusunu ifade eder. Örgütsel güvenden yoksun ortamlarında adaletsizlik hakimdir. Çalışanların onuru, kişiliği ve mesleki yeterliği güven altında değildir. İnançları zedelemek, gerçekleri çarpıtmak, çalışanların etrafında güvensizlik gibi iş doyumunu ve yaşam doyumunu azaltan uygulamalar adeta kurum kültürü haline dönüşür. Yetersiz çalışma koşulları, yetersiz ücret, iş güvensizliği, örgütsel çatışma, işe yabancılaşma ve mobbinge maruz kalma gibi uygulamalar örgütsel güvenin olmadığı iş ortamlarının özellikleridir. 
Örgütsel güven, örgüt içi açık iletişim, karar alma süreçlerinde çalışanların etkin rol alması, bilgi ve enformasyon paylaşımı, örgütsel hislerin ve beklentilerin paylaşımı sayesinde pekişir. Çalışanların yöneticilere duyulan güvenleri, çalışma arkadaşlarına güvenleri ve uygulamalara güven duymaları sayesinde örgütsel güven algıları güçlenir. Çalışanların tutarlılık, dürüstlük, açıklık, sadakat ve yeterlilik algıları örgütsel güven algısını pekiştiren faktörlerdir. Tutarlılık aynı duruma aynı tepkileri vermeyi ve tahmin edilebilirliği, dürüstlük söylenenler ile yapılanlar arasındaki uyumu, açıklık doğru ve gerekli bilginin tam ve zamanında iletilmesini, sadakat paylaşılan duygu ve düşüncelerin paylaşan ile paylaşılan kişi arasında kalmasını, yeterlilik ise güvenilen kişinin teknik ve yönetsel anlamda bilgi ve yeteneğini ifade eder.

Örgüte güven çalışanların örgütsel rollere, ilişkilere, deneyimlere ve örgüte bağl1l1klarına dayanan olumlu beklentilerden kaynaklanır. Çalışanın örgütün sağladığı desteğe ilişkin inancı örgüte güvenin işareti kabul edilir. Örgüte güvenin sağlanması için çalışanlara karara katılma imkânı verilmesi, açık iletişim ve kritik bilgilerin paylaşılması gerekir. Paylaşımcı bir liderlik yaklaşımı, örgütsel yardımlar, firsatların artırılması gibi uygulamalar örgütsel güveni destekler. Performans değerlemede üst yönetimin adil olması da örgüte güveni artırır. Yöneticiye güven, yöneticilerin tutum ve davranışlarının tutarlı olması ve adil olmalarıyla ilgilidir. Yönetici davranışlarının tahmin edilebilir olması ve söz ve davranışları arasındaki uyum yöneticiye güvenin kaynağıdır. Çalışanlar yöneticilerine güven duyduklarında büyük ihtimalle tüm örgüte güven duyacaklarından güven yöneticiler tarafından başlatılması gereken bir süreçtir. Yöneticinin yönetsel yetkinliği ve kişisel tutarlılı̆̆1 güven düzeyini etkiler. Tutarlılık, dürüstlük, yetkinlik, yardımseverlik, ilgili olma çalışanların gözünde yöneticinin güvenilirliğini artıran özelliklerdir. Çalışma arkadaşlarına güven, çalışanların hareketlerine, dürüstlüklerine ve iyi niyetlerine yüklenen inancı ifade eder. Çalışanlar birbirine güven duyduğunda, birbirleriyle bilgi paylaşımına başlarlar ve diğerini kontrol altında tutmaktan vazgeçerler. $\mathrm{Bu}$ da karşılıklı olarak güveni artırır (Tutar, 2016a: 301). Çalışma arkadaşlarına güven, kişinin meslektaşlarının yeterliliğine, adil, itimat edilir ve etik ilkelere bağlı davranışlar göstereceğine dair inancını yansıtır. Bu tür güven çalışanları sözlerinde ve eylemlerinde adaletli davranmaya yöneltir. Çalışma arkadaşlarına güven, çalışanların birbirlerinin çıkarlarını gözetmeleri, birbirlerine yardım etmeleri ve birbirlerine karşı açık ve dürüst olmalarını ifade eden pozitif beklentilerdir

Örgütsel güvenin hem çalışan hem örgüt açısından birtakım yararları vardır. Bunların başında çalışan memnuniyetinin artmasıdır. Çalışanlar arasında yüksek düzeyde güvenin olduğu bir iş ortamı onların daha yüksek morale ve motivasyonlarına katk1 sağlar. Kendilerine güvenildiğini bilen ve başkalarına güvenen çalışanlar daha uyumlu çalışmaktadır. Yüksek düzeyde güven, insan ilişkilerinin gelişmesine, çalışanlar arasındaki formalitenin azalmasına, birbirlerine karşı olumlu duygular beslemelerine yardımcı olur. Örgütsel güven sayesinde örgütlerde iletişim kalitesinin artması beklenir. Yüksek güven düzeyine sahip örgütlerin çalışanları açıkça iletişim kuran ve bilgi paylaşımında bulunan çalışanlardır. Bu tür örgütlerde yönetimden çalışana ve çalışandan yönetime doğru açık ve çok yönlü iletişim vardır. Örgütsel güvenin diğer önemli bir yararı örgütsel bağlılı̆̆ın artmasına katk1 sağlamasıdır. Çalışanın örgüte bağlı olması o örgütte uzun süreli çalışmasının yanında, örgütün çıkarlarını gözetmeyi, iyi imajı korumayı ve gizli bilgileri başkalarıyla paylaşmamayı da ifade eder. Yüksek düzeyde örgütsel güven çalışan bağl1lı̆g yaratmada anahtar bir araçtır. Örgütsel güvenin diğer bir sonucu işbirliğini teşvik etmesidir. Güvenin olmadığı bir ortamda bireyler kendilerini diğerlerinden korumaya çalışırlar (Tutar, 2016a: 299). Takım çalışmasına sıcak bakmazlar ve bağımsız çalışmak isterler. Bunun nedeni takım arkadaşlarına güven duymamalarıdır. İşte güven seviyesinin yüksek olduğu örgütlerde, bireyler takım ruhuyla birlikte hareket ederek aralarında sinerji oluştururlar. Örgütsel güvenin diğer bir katkısı stresi azaltma yeteneğidir. Güven düzeyinin yüksek olduğu örgütlerde stres düzeyi düşük olması beklenir. 


\section{Yöntem}

\section{Araştırmanın Modeli ve Hipotezleri}

Çalışmanın amacı doğrultusunda oluşturulan araştırma modeli ve hipotezleri aşağıdaki gibi belirlenmiştir:

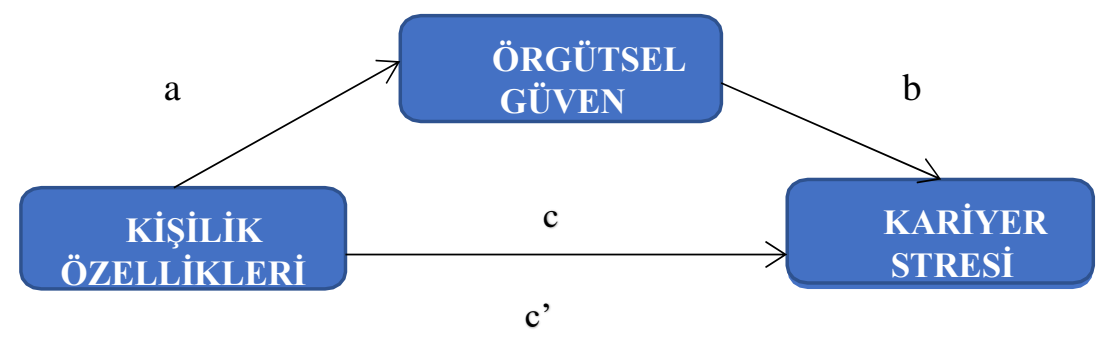

Şekil 1. Araştırmanın Modeli

Yukarıda ifade edilen kuramsal çerçeve doğrultusunda hipotezleri test etmek amaciyla geliştirilen modelde "Kişilik Özellikleri" bağımsız değişken, "Kariyer Stresi” bağımlı değişken, "Örgütsel Güven" ise arac1 (mediatör) değişken olarak düşünülmüştür. Literatür taraması ve araştırmanın genel kurgusu çerçevesinde aşağıdaki hipotezlerin sınanmasına karar verilmiştir.

H1: Katılımcıların kişilik özelliklerinin örgütsel güven düzeyleri üzerine etkisi vardır.

H2: Katılımcıların kişilik özelliklerinin kariyer stresi üzerine etkisi vardır.

H3: Katılımcıların örgütsel güven düzeyinin kariyer stresi üzerine etkisi vardır.

H4: Katılımcıların kişilik özellikleri ile kariyer stresi ilişkisinde örgütsel güvenin aracılık rolü vardır.

\section{Çalışma Grubu}

Araştırmanın çalışma grubu İstanbul'da bir devlet hastanesinde çalışan farklı demografik özelliklere sahip gönüllü 465 katılımcılardan oluşmaktadır. Araştırmada hedef evreni temsil edebilecek unsurların seçilmesi (Neuman ve Robson, 2014:36) amacıyla, örneklemede nicel araştırmalarda sıklıkla kullanılan seçkisiz (amaçsız) basit tesadüfi örnekleme tekniği kullanılmıştır. Çalışmaya ait veriler Ağustos-Ekim 2019 tarihleri arasında toplanmıştır.

\section{Veri Toplama Araçları}

Araştırma verilerini toplamak amacıyla hazırlanan ölçek iki bölümden oluşmaktadır. Birinci bölüm katılımcıların demografik özellikleriyle ilgili, ikinci bölüm ise kişilik özellikleri, kariyer stresi ve örgütsel güven düzeyini belirlemeye yöneliktir.

Kişilik Özellikleri Ölçeği: Araştırmada kişilik özellikleri ile ilgili veriler Goldberg (1992:26) tarafından geliştirile Beş Faktör Kişilik Envanteri aracıllğıyla toplanmıştır. Ölçeğin Türkçe uyarlaması Tatar (2017: 51) tarafından yapılmıştır. 220 madde ve 17 alt boyutlu ölçeğin geniş örneklemlere uygulanmasının zor olması ve sağlıksız sonuçlar elde edilmesi nedeniyle ölçeğin 5 alt boyuta indirgemesi yapılan 50 maddeden oluşan kısa versiyonu geliştirilmiştir. Ölçek, Dışadönüklük, Uyumluluk, Sorumluluk, Duygusal Dengesizlik ile Zeka ve Hayal Gücü'nü ölçmektedir. Alt boyutlardan alınan puanlar 1-5 arasında değişmektedir. Alınan yüksek puanlar, o kişilik özelliğinin yüksek olduğunu göstermektedir. Araştırmada 50 maddelik kısa versiyonu kullanılmıştır.

Kariyer Stresi Ölçeği: Bu çalışmada Kariyer Stresi Ölçeği (KSÖ), kariyerle ilgili stres kaynaklarını ve stresin sonuçlarını ölçmek ölçmek amacıyla Choi ve arkadaşları (2011) tarafından 
geliştirilen ölçek kullanılmıştır. Ölçek, toplam 20 maddeden ve 3 alt boyuttan (kariyer belirsizliği ile bilgi eksikliği, iş bulma baskısı ve dışsal çatışma) oluşmakta olup katılımcılardan ifade edilen durumlara kendileriyle ilgili olarak ne düzeyde katıldıklarını "Hiç katılmıyorum (1)" ile "Tamamen katılıyorum (5)" arasında değişen 5'li Likert tipi bir ölçekte değerlendirmeleri istenmiştir.

Örgütsel Güven Ölçeği: Araştırmada katılımcıların örgütsel güven algılarını belirlemek amacıyla; Whitener ve diğerlerinin (1998) geliştirdiği yönetsel ve güvenirlik modelinden, yöneticiye güven düzeylerini belirlemek için, Mayer ve diğerlerinin (1995) geliştirdikleri güven modelinden ve çalışma arkadaşlarına güven seviyelerini belirlemek için, McAllister'in (1995) geliştirdiği kişilerarası güven ölçeğinden faydalanmıştır. Ölçeğin yapı geçerliliğinin test edilmesi amacıyla ön test uygulanmış ve geliştirilen bu ölçeğin güvenirlik değeri Cronbach alfa değeri $\alpha=0,96$ bulunmuştur (Tokgöz, 2012:101). Belirtilen ölçüm araçlarının tümünde beşli Likert ölçeği kullanılmıştır.

Ölçeklerin Geçerliliği ve Güvenilirliğine İlişkin Bulgular: Araştırmada kullanılan değişkenlerin faktör yapısını belirlemek için Temel Bileşenler Analizi (Principal Componentes Analysis) ve faktör gruplarını oluşturmak için Varimaks Dönüştürmesi (Varimax Rotation) kullanılmıştır. Verilerin faktör analizine uygunluğu Keiser-Meyer-Olkin (KMO) ve Barlette Küresellik Testleri ile ortaya konulmuştur. Güvenilirliğin belirlenebilmesi amaciyla Cronbach'a Alfa değeri yapılan analiz sonrası kontrol edilmiştir. Uygulanan analiz sonucunda kullanılan ölçeğin güvenilir olarak kabul edilen istatistiki değer aralığında yer aldığı belirlenmiştir. Kişilik özellikleri, kariyer stresi ve örgütsel güven ölçeklerinin daha önce yapılan çalışmalar ile geçerlilik ve güvenilirlikleri kontrol edildiğinden, çalışmada ölçeklerin yalnızca güvenilirlik ve açımlayıcı faktör analizleri yapılmıştır. Aralarında ilişki olduğu varsayılan çok sayıdaki değişkenin arasındaki ilişkiyi anlamak ve yorumlamak amacıyla öz değerlerin 1'den büyük olan değişkenlerden faktörlerin oluşumuna sağlanmıştır (Özdamar, 1999:522). Kişilik özellikleri için yapılan açımlayıcı faktör analizinde ölçeğin beş boyutlu bir yapı ve toplam varyansın \%65,346'sini açıladığ1 görülmüsstür. Ölçeğin KMO değeri .812 ve Barlette Küresellik Test sonucu anlamlıdır (Sig=0,000).

Kariyer Stresi için yapılan açımlayıcı faktör analizinde ölçeğin üç boyutlu bir yapı ve toplam varyansın \%69,144'ünü açıkladığı görülmüştür.

Tablo 1: Ölçeklere İlişkin Güvenilirlik Katsayıları

\begin{tabular}{|c|c|c|}
\hline Ölçekler & Boyutlar & $\begin{array}{c}\text { Cronbach } \\
\text { Alfa Katsaylst }\end{array}$ \\
\hline \multirow{5}{*}{$\begin{array}{c}\text { KİŞILIK } \\
\text { ÖZELLIKLERİ }\end{array}$} & Dişadönüklük & 0.82 \\
\hline & Uyumluluk & 0.836 \\
\hline & Sorumluluk & 0.851 \\
\hline & Duygusal Denge & 0.818 \\
\hline & Zeka ve Hayalgücü & 0.809 \\
\hline \multirow{3}{*}{$\begin{array}{c}\text { KARIYER } \\
\text { STRESİ }\end{array}$} & Kariyer Belirsizliği ile Bilgi Eksikliği & 0.901 \\
\hline & İş Bulma Baskıs1 & 0.845 \\
\hline & Dişsal Çatışma & 0.843 \\
\hline \multirow{3}{*}{$\begin{array}{c}\text { ÖRGÜTSEL } \\
\text { GÜVEN }\end{array}$} & Kuruma Güven & 0.901 \\
\hline & Yöneticiye Güven & 0.856 \\
\hline & Çalışana Güven & 0.812 \\
\hline
\end{tabular}

Ölçeğin KMO değeri .851 ve Barlette Küresellik Test sonucu anlamlıdır (Sig=0,000). Örgütsel Güven için yapılan açımlayıcı faktör analizinde ölçeğin üç boyutlu bir yapı ve toplam 
varyansın \%63,878'ini açıkladığı görülmüştür. Ölçeğin KMO değeri .876 ve Barlette Küresellik Test sonucu anlamlıdır. (Sig=0,000). Ölçeğin Cronbach Alpha güvenirlik katsayıları, Tablo 1'de verilmiştir.

\section{Verilerin Analizi}

Veri analizi kapsamında; faktör analizi, farklılık testleri, korelasyon ve regresyon analizleri yapılarak demografik değişkenler üzerinde tanımlayıcı istatistik analizleri yapılmıştır. Araştırmada verilerin analizinde SPSS paket programı kullanılmıştır.

\section{Bulgular}

\section{Demografik Verilere İlişkin Bulgular}

Katılımcıları demografik özellikleri bakımından cinsiyet, yaş, medeni durum, mesleki deneyim ve aylık ücret bakımından değerlendirilmiştir. Demografik değişkenlere ilişkin detaylı bilgilere Tablo 2'de yer verilmiştir. Bu çerçevede çalışanların 197'si (\% 42,37) kadın, 113'ü $(\% 24,30)$ 26-30 yaş arası, 250'si $(\% 53,76)$ evli, 185'i $(\% 39,78)$ lisans mezunu, 121'i $(\% 26,02)$ 1-5 yıl arası mesleki deneyimi olduğu ve $204(\% 43,87)$ çalışanın 3001-5000 TL arası aylık geliri olduğu tespit edilmiştir.

Tablo 2: Demografik Değişkenlere İlişkin Sonuçlar

\begin{tabular}{|c|c|c|c|}
\hline & & $\mathbf{N}$ & $\%$ \\
\hline \multirow{2}{*}{ Cinsiyet } & Kadın & 197 & 42,37 \\
\hline & Erkek & 268 & 57,63 \\
\hline \multirow{7}{*}{ Yaş } & $20-25$ & 173 & 37,20 \\
\hline & $26-30$ & 113 & 24,30 \\
\hline & $31-35$ & 45 & 9,68 \\
\hline & $36-40$ & 17 & 3,66 \\
\hline & $41-45$ & 69 & 14,84 \\
\hline & $46-50$ & 30 & 6,45 \\
\hline & $51-\Uparrow$ & 18 & 3,87 \\
\hline \multirow{2}{*}{ Medeni Durum } & Evli & 250 & 53,76 \\
\hline & Bekar & 215 & 46,24 \\
\hline \multirow{5}{*}{ Eğitim Düzeyi } & Lise & 74 & 15,91 \\
\hline & Önlisans & 126 & 27,10 \\
\hline & Lisans & 185 & 39,78 \\
\hline & Yüksek Lisans & 50 & 10,75 \\
\hline & Doktora & 30 & 6,45 \\
\hline \multirow{5}{*}{$\begin{array}{c}\text { Kurumdaki Hizmet } \\
\text { Süresi }\end{array}$} & 1 yildan az & 187 & 40,22 \\
\hline & $1-5 y_{11}$ & 121 & 26,02 \\
\hline & $6-10 \mathrm{y} 11$ & 79 & 16,99 \\
\hline & $11-15$ y1l & 32 & 6,88 \\
\hline & $16-20 \mathrm{y} 1 \mathrm{l}$ & 46 & 9,89 \\
\hline \multirow{6}{*}{ Aylık Gelir Düzeyi } & 3000 TL Den Az & 129 & 27,74 \\
\hline & $3001-5000$ & 204 & 43,87 \\
\hline & $5001-7000$ & 62 & 13,33 \\
\hline & $7001-9000$ & 37 & 7,96 \\
\hline & $9001-12000$ & 14 & 3,01 \\
\hline & 12001 ve Üzeri & 19 & 4,09 \\
\hline
\end{tabular}




\section{İlişkisel Analiz, Bulgulart}

Öncelikle verilerin normal dağılım gösterip göstermediği kontrol etmek amacıyla çarpıklık (Skewness) ve basıklık (Kurtotis) değerleri kontrol edilmiştir. Normal dağılım değer aralığının ne olması gerektiği konusuyla ilgili çeşitli görüşler olmasına karşıı bu çalışmada Tabachnick ve Fidell (2007) çalışmalarında belirttikleri $\pm 1,5$ güven aralığı içerisinde olması koşulu üzerinden değerlendirme yapılmıştır.

Tablo 3: Araştırma Değişkenleri Arasındaki İlişkiler

\begin{tabular}{|l|l|c|c|c|}
\hline & \multicolumn{1}{|c|}{$\begin{array}{c}\text { KARIYER } \\
\text { STRESI }\end{array}$} & KișiLiK & $\begin{array}{c}\text { ÖRGÜTSEL } \\
\text { GÜVEN }\end{array}$ \\
\hline KARIYER STRESI & $\begin{array}{l}\text { Pear.Correlation } \\
\text { Sig.(2-tailed) }\end{array}$ & 1 & $.367^{* *}$ & $.255^{* *}$ \\
\hline KIŞiLiK & $\begin{array}{l}\text { Pear.Correlation } \\
\text { Sig.(2-tailed) }\end{array}$ & $.367^{* *}$ & 1 & $.708^{* *}$ \\
\hline $\begin{array}{l}\text { ÖRGÜTSEL } \\
\text { GÜVEN }\end{array}$ & $\begin{array}{l}\text { Pear.Correlation } \\
\text { Sig.(2-tailed) }\end{array}$ & $.255^{* *}$ & $.708^{* *}$ & 1 \\
\hline
\end{tabular}

Yapılan analiz sonucu verilerin belirtilen değer aralığında çarpıklık ve basıklık değerlerine sahip olduğu ve veri dağılımının normallik varsayımını karşıladığı anlaşılmıştır. Daha sonra yapılan korelasyon analizi sonuçları kişilik özellikleri ile kariyer stresi $\left(\mathrm{r}=.367^{* *}\right)$, kariyer stresi ile örgütsel güven $\left(\mathrm{r}=.255^{* *}\right)$ arasında pozitif ve düşük düzeyde bir ilişkinin olduğu anlaşılmıştır. Ayrıca korelasyon analizi sonuçları kişilik özellikleri ile örgütsel güven $\left(\mathrm{r}=.708^{* *}\right)$ aralarında pozitif yönlü ve yüksek düzeyde bir ilişkinin varlığını ortaya koymaktadır.

İlişkiler alt boyutlar düzeyinde değerlendirildiğinde, kişilik özelliklerinin alt boyutu olan sorumluluk, duygusal denge, zeka ve hayal gücünün kariyer belirsizliği dışında yer alan dışsal çatı̧̧ma, kuruma güven, yöneticiye güven ve çalışanlara güven boyutları ile pozitif yönlü bir korelasyona sahip olduğunu, "dışsal çatışma"nın kişilik özelliklerine ait uyumluluk, sorumluluk, duygusal dengesizlik ve zeka ve hayal gücü arasında pozitif yönlü ve güçlü bir ilişki ile örgütsel güvenin alt boyutları örgüte güven, yöneticiye güven ve çalışana güvenlede pozitif yönlü ve güçlü bir korelasyonun varlığını ortaya koymaktadır. Analizlere ilişkin detaylı bilgiler Tablo 4'de yer almaktadir.

Tablo 4: Araştırma Değişkenlerinin Alt Boyutları Arasındaki İlişkiler

\begin{tabular}{|c|c|c|c|c|c|c|c|c|c|c|c|}
\hline & $\mathrm{K} B$ & DC & $\mathrm{IBB}$ & DDD & UYM & SRM & DUD & ZHIG & KG & YG & CG \\
\hline KB & 1 & & & & & & & & & & \\
\hline DC & $.176 * *$ & 1 & & & & & & & & & \\
\hline IBB & $.226^{* *}$ & $.112^{* * *}$ & 1 & & & & & & & & \\
\hline DD & $.240 * *$ & $.387 * *$ & $.397 * *$ & 1 & & & & & & & \\
\hline UYM & $.340^{* * *}$ & $.389 * *$ & $.199 * *$ & $.399 * *$ & 1 & & & & & & \\
\hline SRM & $.360 * *$ & $.352^{* * *}$ & $.109 *$ & $.442 * *$ & $.325 * *$ & 1 & & & & & \\
\hline DUD & $.192 * *$ & $.372 * *$ & $.189 * *$ & $.418^{* * *}$ & $.416 * *$ & $.423 * *$ & 1 & & & & \\
\hline ZHG & $.392 * *$ & $.380 * *$ & $.219 * *$ & .415 ** & $.419 * *$ & $.394 * *$ & $.326^{* *}$ & 1 & & & \\
\hline KG & $.287 *$ & $.434 * *$ & $.139 *$ & $.376 * *$ & $.305^{* *}$ & $.350 * *$ & $.426 * *$ & $.426^{* * *}$ & 1 & & \\
\hline YG & $.327 *$ & $.325 * *$ & $.102 *$ & $.394 * *$ & $.396 * *$ & $.374 * *$ & $.362^{* * *}$ & $.641 * *$ & $.392^{*}$ & 1 & \\
\hline CG & $.227 *$ & $.400^{* * *}$ & $.219^{*}$ & $.345 * *$ & $.332 * *$ & $.430 * *$ & $.446 * *$ & $.657^{* *}$ & $.411 * *$ & $.587 * *$ & 1 \\
\hline $\begin{array}{l}\text { KB } \\
\text { DC } \\
\text { IBB } \\
\text { DD }\end{array}$ & $\begin{array}{l}\text { Kariyer } \\
\text { 1şsal Ç} \\
\text { ş Bulma } \\
\text { Oş̧a Dör }\end{array}$ & $\begin{array}{l}\text { lirsizliz } \\
\text { 1şma } \\
\text { Baskıs1 } \\
\text { iklük }\end{array}$ & & $\begin{array}{l}\text { UY } \\
\text { SRI } \\
\text { DU } \\
\text { ZH }\end{array}$ & $\begin{array}{l}\text { : Uyu } \\
\text { : Soru } \\
\text { : Duy } \\
\text { : Zek }\end{array}$ & $\begin{array}{l}\text { luluk } \\
\text { lluluk } \\
\text { usal Den } \\
\text { ve Haya }\end{array}$ & & $\begin{array}{l}\text { KG } \\
\text { YG } \\
\text { CG }\end{array}$ & $\begin{array}{l}\text { : Kuru } \\
\text { : Yöne } \\
\text { : Çalış }\end{array}$ & $\begin{array}{l}\text { a Güve } \\
\text { me Güv } \\
\text { aüven }\end{array}$ & \\
\hline
\end{tabular}

Turkish Studies, 15(2) 


\section{Aracıllk Etkisi Analizleri}

Geleneksel yaklaşımı (nedensellik) benimseyen Baron ve Kenny yöntemi aracılık modellerinin analizinde yaygın şekilde kullanılmaktadır. Kullanılan bu yöntemde aracılık etkisinin tespit edilebilmesi için Baron ve Kenny dört ana şartın yerine getirilmesi gerektiğini ifade etmektedir (Baron ve Kenny, 1986:1176).

- Bağımsız değişken, aracı değişkeni anlamlı etkilemelidr.

- $\quad A r a c ı$ değiş̧ken, bağımlı değişken anlamlı olarak etkilemelidr.

- $\quad$ Bağımsız değişken, bağımlı değişken anlamlı olarak etkilemelidir.

- $\quad$ Aracı değişken modele katıldığında bağımsız değişkenin bă̆ımlı değiş̧ken üzerindeki etkisi azalmaktadır.

Aracılık (mediation) etkisi analiz çalışmaları üç farklı istatistiki analiz karşımıza çıkmaktadır. Bunlar

1. Regresyon temelli analiz

2. Yapısal eşitlik modellemesi

3. PROCESS macrosu aracılığıyla analiz olarak sınıflandırılabilir. Sosyal bilimlerde yapılan çalışmalarda dağılımın normalliği ve simetrik ilişkinin varlığının olmadığı varsayılmaktadır.

Çalışmamızda aracı etkinin kontrol edilebilmesi için Andrew Hayes'in geliştirdiği SPSS tabanlı PROCESS makrosunun 4. Modeli kullanılmıştır. Baron ve Kenny (1986) belirttiği aracı değişkenin sahip olması gereken ilişkilerden ilki olan bağımsız değişkenin aracı değişkeni doğrudan etkilemesi şartı model kapsamında analiz edilmiștir. Analiz sonuçları Tablo 5'de yer almaktadır. Bu çerçevede kişilik özellikleri ile örgütsel güven arasında istatistik anlamlı bir ilişki tespit edilmiştir $(\mathrm{p}<0,05)$. Bu analiz sonucu, Baron ve Kenny'nin (1986) ifade ettiği ilk ilişkinin (a yolu) varlığını ortaya koymaktadir.

Araştırma değişkenleri arası etkinin test edildiği sonuç aynı zamanda çalışanların kişilik özelliklerinin örgütsel güvenlerini anlamlı düzeyde ve olumlu yönde etkilediğini göstermektedir. Anlamlı ilişkinin varlığı LLCI-ULCI değerlerinin 0 (sıfır) değerinin kapsamamasından ve $(p<0,05)$ anlaşılmaktadır. Kısacası "çalışanların kişilik özelliklerinin olumluluk düzeyleri örgütsel güven düzeyini de arttırmaktadır."

Tablo 5: Kişilik Özelliklerinin Örgütsel Güven Üzerindeki Etkisi

\begin{tabular}{|c|c|c|c|c|c|c|c|c|}
\hline & B & S.H & $\mathbf{T}$ & $\mathbf{p}$ & LLCI & ULCI & $\mathbf{P}$ & R2 \\
\hline \multicolumn{7}{|c|}{ REGRESYON ANALIZ SONUÇLARI } & \multicolumn{2}{|c|}{ MODEL ÖZETİ } \\
\hline $\begin{array}{l}\text { Örgütsel } \\
\text { Güven }\end{array}$ & 9209 & .0198 & 46.5811 & .0000 & .8820 & .9597 & .0000 & .2610 \\
\hline
\end{tabular}

Analizin ikinci bölümünde aracı değişken olan örgütsel güvenin (b yolu) kişilik özellikleri değiş̧keninin (c'yolu) bağımlı değişken olan kariyer stresi üzerindeki birlikte etkisi incelenmiştir. Analiz sonuçlarına ait bilgiler Tablo 5'da yer almaktadır. Bu sonuçlara göre $\mathbf{H 1}$ hipotezi doğrulanmıştır. 
Tablo 6: Örgütsel Güvenin Kariyer Stresi Üzerindeki Etkisinde Kişilik Özelliklerinin Rolü

\begin{tabular}{|c|c|c|c|c|c|c|c|c|}
\hline \multirow{2}{*}{\multicolumn{7}{|c|}{$\begin{array}{ccc}\text { B } & \text { S.H } & \text { T } \\
\text { REGRESYON ANALIZ SONUÇLARI }\end{array}$}} & & 22 \\
\hline & & & & & & & \multicolumn{2}{|c|}{ MODEL ÖZETİ } \\
\hline $\begin{array}{l}\text { Kişilik } \\
\text { Özellikleri }\end{array}$ & .6974 & .0894 & 7.5972 & .0000 & .5037 & .8552 & \multirow{2}{*}{.0000} & \multirow{2}{*}{1688} \\
\hline $\begin{array}{l}\text { Örgütsel } \\
\text { Güven }\end{array}$ & .3858 & .0882 & -4.3759 & .0000 & -.5590 & -.2125 & & \\
\hline
\end{tabular}

Yapılan analiz sonuçları kariyer stresinin modele dahil edilmesi ile örgütsel güvenin ilgili değişken üzerindeki etkisinin istatistiki olarak anlamlı $(\mathrm{p}<0,05)$ varlığını ortaya koymaktadır. Kısacası örgütsel güven kariyer stresini anlamlı düzeyde ve negatif yönde etkilemektedir ( $\beta=.3858$, \%95, LLCI-ULCI:-.5590/-.2125). Ayrıca analiz sonuçları kişilik özelliklerinin kariyer stresi üzerinde anlamlı bir etkisinin olduğunu ortaya koymaktadır. Kişilik özellikleri ve kariyer stresindeki değişimin yaklaşık \%17'ini (R2=.1688) açıklamaktadır. Bu çerçevede araştırmanın test edilmek üzere ileri sürülen $\boldsymbol{H} \mathbf{2}$ ve $\boldsymbol{H 3}$ hipotezlerinin doğrulandığı anlaşılmıştır.

Son analizde; bağımsız değişken üzerinde doğrudan etkisi bulunan aracı değişken modele dahil edilmiştir. Baron ve Kenny'nin (1986) son önermesi aracı değişken modele dahil edildiğinde; bağımsız değişkenden bağımlı değişken tanımlanan etki değerinin düşmesi gerektiği şeklindedir. Yapılan bu analizler kişilik özellikleri değişkeninin aracı değişken (örgütsel güven) aracılığıyla kariyer stresi üzerindeki direkt ve dolaylı etkilerini ortaya koymaktadır. Direkt etkide kişilik özelliklerinin aracı değişken (örgütsel güven ) olmadan kariyer stresi üzerindeki etkisini ortaya koyarken, indirekt etki ise aracı değişkenin (örgütsel güvenin) analize dahil edilmesi etki düzeyinin istatistiki olarak anlamsız hale gelmesi ya da etki değerinin düşmesi beklenmektedir. Yapılan analize ilişkin detaylı bilgi Tablo 7'de yer almaktadır.

Tablo 7: Aracı Etki Analizi Sonuç Tablosu

\begin{tabular}{ccccccccc}
\hline & $\begin{array}{c}\text { Direkt } \\
\text { Etki }\end{array}$ & $\begin{array}{c}\text { Dolaylı } \\
\text { Etki }\end{array}$ & $\mathbf{S . H}$ & $\mathbf{Z}$ & $\mathbf{P}$ & $\begin{array}{c}\text { Bootstrap } \\
\text { Güven } \\
\text { Aralı̆ğ } \\
\text { BoLLC I }\end{array}$ & $\begin{array}{c}\text { Bootstrap } \\
\text { Güven } \\
\text { Aralı̆ğ } \\
\text { BoULC I }\end{array}$ & $\begin{array}{c}\text { Araciltk } \\
\text { Etkisi }\end{array}$ \\
\hline $\begin{array}{c}\text { Örgütsel } \\
\text { Güven }\end{array}$ & 0.6794 & 0.3553 & 0.0894 & 0.2345 & 0.000 & -.5270 & -.1810 & $\begin{array}{c}\text { Kracmi } \\
\text { Etkisi } \\
\text { Vardır }\end{array}$ \\
\hline
\end{tabular}

Analiz sonuçları değerlendirildiğinde kişilik özellikleri örgütsel güvenin kariyer stresi üzerindeki etkisi etkileşim değişken aracılığıyla tespit edilmektedir. Çalışmamızda, $\boldsymbol{\beta}$ etkileşim değeri 0.6794 olarak bulunurken, aracı değişkeninde modele dahil edilmesiyle etki değerinin $\boldsymbol{\beta}$ 0.3553'e gerilediği görülmektedir. Dördüncü önermede bu bağlamda kabul edilmiş kişilik özelliklerinin kariyer sresi üzerindeki etkisinde örgütsel güvenin kısmi bir aracılık etkisinin olduğunu ve bu etkinin $(\mathrm{p}<0.05)$ istatistiki anlamlılığ ortaya koymaktadır. Ayrıca analiz sonuçları dolaylı etki değeri (0.3553) iki çalışandan kişilik özelliklerinin etki düzeyi diğer çalışandan bir birim yüksek olan bir çalışanın (kişilik özellikleri etki düzeyi yüksek olan bir çalışanın örgütsel güven düzeyinin daha yüksek olması ve örgütsel güven düzeyi yükssek olan çalışanın kariyer stresi düzeyinin daha düşük olması nedeniyle) yaşam tatmini düzeyinin .3553 birim düşük olduğunu ortaya koymaktadır. $\mathrm{Bu}$ bağlamda Hayes Process analiz sonuçları "Kişilik özellikleri ve kariyer stresi ilişkisinde örgütsel güvenin kısmi aracı bir etkiye" sahip olduğunu ortaya koymaktadır. Bu çerçevede araştırmanın test edilmek üzere ileri sürülen $\boldsymbol{H} \mathbf{4}$ hipotezlerinin doğrulandığı anlaşılmıştır.

\section{Sonuç ve Öneriler}

Kişilik özellikleri, güven düzeyini etkileyen önemli bir değişkendir. Literatürde kişilik özellikleri ve örgütsel güvenin bir arada ele alındığı çalışmalar bulunmakla birlikte, özellikle kariyer 
stresi ile diğer değişkenleri berlikte değerlendiren bir çalışmaya rastlanmamıştır. Bu yönüyle araştırma sonuçlarının literetüre katkı sağlayacağı düşünülmektedir. $\mathrm{Bu}$ doğrultuda araştırma sonuçları değerlendirildiğinde kişilik özelliklerinin alt boyutlarının (dışadönüklük, uyumluluk, sorumluluk, duygusal dengesizlik ile zekâ ve hayal gücü) ile örgütsel güven arasında pozitif bir ilişkinin varlığını ortaya koymaktadır. Kuruma güven, örgüte güven ve çalışana güven, kişilik özelliklerinin tüm alt boyutlarıyla pozitif ilişkisi olduğu ortaya konulmuştur. Çalışanların güven düzeyleri arttıkça, sorumluluk alma, uyumlu olma, dışa dönüklük ve duygusal denge düzeyi armakta, bu durum örgüte yarar sağlayabilecek fikirlerini paylaşma eğilimlerinin yükseltmektedir. Çalışanların dışadönük, uyumlu, sorumlu ve açık görüşlü kişilik özelliklerine sahip olmaları, güven düzeylerini olumlu yönde etkilemekte ve pozitif davranışlar göstermelerine neden olabilmektedir. Benzer şekilde alan yazınında, güvenin kişilik özelliklerinden etkilendiğini ortaya koyan çalışmalar ile (Hiraishi, Yamagata, Shikishima ve Ando 2008) kişilik özelliklerinin güven üzerinde önemli bir etkisi olduğunu (Mooradian, Renzl ve Matzler, 2006; Quinlan, 2008; Furumo, Pillis ve Green, 2009; Alsajjan, 2010; Sicora, 2014) ortaya koyan çalışmalar bulunmaktadır. Kişilik özelliklerinin alt boyutlarından dışa dönüklük, uyumluluk ve sorumluluk boyutlarının, örgütsel güven üzerinde etkisini ortaya koyan çalışmalar da bulunmaktadır (Evans ve Revelle, 2008; Sicora,2014; Bergman, Small, Bergman ve Rentsch, 2010). Bu çalışmalardan Karkoulian ve Osman (2009), uyumlu kişilik özelliklerine sahip bireylerin, olumlu kişiler arası ilişkilere sahip olduğunu ve güven düzeylerinin daha yüksek olduğun sonucuna ulaşmıştır.

Sicora (2014), kişilik özellikleri ile güven arasındaki ilişkiyi belirlemek amacıyla yaptığı çalışmada uyumluluk ve duygusal denge düzeyi yüksek olan çalışanların, örgütsel güven düzeylerinin de yüksek olduğunu tespit etmiştir. Çalışanların, lidere olan güveninin uyumluluk, sorumluluk ve açık görüşlü olmak şeklinde ifade edildiği çalışmanın ortaya koyduğu diğer bulgulardandır. Birey içe dönük bir kişilik özelliğine sahipse ya da yalnız kalmayı başkaları ile zaman geçirmeye tercih ediyorsa, bu bireyin başka bireylerle ilişki kurmasının ve güven duymasının diğerlerine göre daha zor olacağı anlamına gelmektedir. Benzer şekilde sorumluluk sahibi kişilik özelliğine sahip bireyler, örgütler ve yöneticiler tarafından aranan çalışanlar olarak tanımlanırken, diğer grupların birlikte olmak istediği ve güven duyduğu bireyler olarak tanımlanmaktadır. Karkoulian ve Osman (2009:177) yapmış oldukları çalışmada, uyumlu bireylerin başarılı kişiler arası ilişkilere sahip olduğunu ve güven duyma eğiliminde olduğunu, nevrotik bireylerin ise daha zor güven geliştirdiği ve işbirliğine daha az yatkın olduklarını ortaya koymuştur. Evans ve Revelle (2008:1585) yaptıkları çalışmada uyumluluk düzeyi yüksek çalışanların, diğer bireylerin iyi niyetli olduğuna inanmasının daha kolay olduğu ve güven düzeyinin daha yüksek olduğunu ortaya koymuştur. Bu doğrultuda araştırma sonuçları literatür ile pararlelilk göstermektedir.

Çalışanların kişilik özellikleri örgütsel güven, örgütsel performans, başarı, olumlu kişiler arası ilişkiler ve verimlilik açısından önemli bir değişkendir. Çalışmamzda, uyumluluk, sorumluluk, duygusal denge gibi kişilik özelliklerinin örgütsel güvenin oluşturulması açısından önemli bir değiş̧en olduğunu ortaya koymaktadır. Kişilik özellikleri ve kariyer stresi ilişikisine, örgütsel güvenin aracılık etkisini dâhil ettiğimizde uyumlu, sorumluluk düzeyi yüksek ve dişa dönük kişililk özelliklerine sahip çalışanların, örgütlere farklı alanlarda daha yararlı olacakları ileri sürülebilir. Çalışmanın ortaya koyduğu sonuçlardan bir diğeri de kariyer stresinin, kişilik özellikleri ile örgütsel güven arasında istatistiki olarak anlamlı ilişkinin olduğudur. Bu ilişkide en yüksek korelasyonun zeka ve hayal gücü, sorumluluk ve uyumluluk ile kariyer belirsiliği ve çatışma arasında olduğunu ortaya koymaktadır. İş bulma baskısı ile kişilik özellikleri arasındaki korelasyon ise düşük seviyede bulunmuştur. $\mathrm{Bu}$ çerçevede literatürde meslek ve iş yaşamınındaki problemlerle başa çıkmasında kişilik özelliklerinin önemi belirtilmektedir (Savickas, 2002; 2005; Creed, Patton ve Bartrum, 2002; Creed, Fallon ve Hood, 2009; Hackett ve Byars, 1996; Lent Brown ve Hackett, 1994). Örgütsel güvenin, kişilik özellikleri ve kariyer stresi ilişkisinde aracı bir etkiye sahip olduğı araştırmanın ortaya koyduğu önemli sonuçlardan biridir. Çalışanların kişilik özellliklerinin bilinmesi ve buna göre 
muamele yapılması, kariyer sttresinin azaltılmasında rol oynayabileceği gibi, kişinin örgütsel güven algısının gelişmesine katkı sağlayabileceği ileri sürülebilir.

Araştırma sonuçları değerlendirildiğinde performans, örgütsel vatandaşlık, örgütsel bağl1lık gibi örgütün gelişimine katkı sağlayacak, çalışanın örgüte yönelik davranışları üzerinde pozitif etkisi olan örgütsel güven, örgütsel adalet, kişiler arası ilişsiler, bilgi paylaşımı gibi faktörlerden etkilenmekle birlikte, kişilik özelliklerinden de etkilendiği söylenebilir. Bu çerçevede işe alım süreci ve örgütsel problemlerin belirlenmesi ve bazı davranışların önceden tanımlanabilmesinde, kişilik özelliklerinin bilinmesi önemlidir. Kişilik özelliklerinin belirlenmesi, çalışanların davranışlarının örgütün istediği şekilde yönlendirilmesi, performansın ve motivasyonun arttırılmasında yönlendirici olacağ 1 bir varsayım olarak ileri sürülebilir. Bu çalışma ve literatürde yapılan benzer çalışmaların sonuçlarından yararlanılarak, kişilik özelliklerinin kariyer stresiyle ilişkili olduğu, ayrıca örgütsel güven algısının bu ilişkide aracı bir etkiye sahip olduğundan hareketle kişilik özelliklerinde uyumluluk, dışa dönüklük ve sorumluluk düzeyi yüksek çalışanların örgüte katkı sağlayacak davranışları arttırıcı bir rol oynadığı sonucuna ulaşılabilir. Bu çerçevede örgüt yöneticileri, işe alım süreci, ekip çalışması, terfide ve çeşitli kademelerde görevlendirilecek personelin belirenmesinde kişilik özelliklerinin dikkate alınması, sorumluluk, uyumluluk ve dışa dönüklük bağlamında değerlendirilerek çalışanların tercih edilmesi örgüt yararına olacaktır. İnsan kaynakları departmanı tarafından kişilik testlerinin işe alım sürecinde aktif olarak kullanılması doğru personelin seçiminde önemli rol oynayabilir. Yöneticilerin, çalışanların kişilik özelliklerini değerlendirerek uyumluluk, sorumluluk sahibi olmak gibi özellikleri daha belirgin olan çalışanlara bilgi paylaşımı ve yönetim sürecine dâhil etmesi örgüt ve diğer çalışanlar açısından olumlu algının oluşturlmasına katkı sağlayabilir. Kişilik özelliklerinin farklılı̆̆ına saygı gösterilmesi güvene dayalı ilişkilerin gelişmesinde yararlı olabilir. Çalışanların kariyer stresi nedenlerinin tespit edilmesi ve bunların ortadan kaldırılması, çalışanların örgütsel güven düzeylerini arttırabileceği gibi performansın arttırılmasına da katkı sağlayabilir.

$\mathrm{Bu}$ çalışma bir kamu hastanesi ile sınırlı tutulmuştur. Benzer bir çalışma kamuya ait farklı sektörler ile özel hastanelerde veya hizmet sektöründe faaliyet gösteren örneklemlerde tekrarlanabilir. Çalışma sadece sağlık çalışanları üzerinde yapılmıştır. Farklı meslek grupları çalışma kapsamına alınması, karşılaştırma ve değerlendirme yapılabilmesi açısından faydalı olacaktır. Araştırma İstanbul ile sınırlı kalmıştır. Farklı bölgelerde ve şehirlerde benzer çalışmanın yapılması karşılaştırma yapmaya imkan sağlayacaktır. Ayrıca bu konuda yapılacak meta analizlerle araştırmanın geçerliliği artırılabilir. Araştırma değişkenleri olarak kariyer stresi, kişilik özellikleri ve örgütsel güven olarak belirlenmiştir. Aracı değişken olarak farklı örgütsel davranış konuları kullanılabilmesi, araştırma değişkenleri arası ilişkilerin belirlenmesine katkı sağlayacaktır.

\section{Kaynakça}

Alsajjan, Bander A. (2010). "How the big five personality dimensions influence customers trust in uk cellular providers?” International Journal of Global Business, 3(1): 102-116.

Allport, G.W. (1952). The mature personality. Pastoral Psychol 3:19-24.

Antonioni, D. (1998). "Relationship between the big five personality factors and conflict management styles" International Journal of Conflict Management, 9(4): 336-355.

Baltaş, A. ve Baltaş Z. (1999). Stres ve başa çıma yolları. İstanbul: Remzi Kitabevi.

Baron, R. M. ve Kenny, David A. (1986). "The moderator-mediator variable distinction in social psychological research: conceptual, strategic, and statistical considerations." Journal of Personality and Social Psychology, 51(6):1173-1182 
Bergman, J. Z., Small, E. E., Bergman, S. M. ve Rentsch, J. R. (2010). "Asymmetry in perceptions of trustworthiness: $1 t^{\text {"s }}$ not you; $1 t^{\text {ee }}$ me." Negotiation and Conflict Management Research, 3:379-399.

Bowditch, J. L. ve Buono A. F. (2005). A primer on organizational behavior. Hoboken, NJ: John Wiley.

Choi, B. Y., Park, H. R., Nam, S. K., Lee, J. ve Lee, S. M. (2011). "The development and initial psychometric evaluation of the Korean Career Stress Inventory for college students." Career Development Quarterly, 59:559-572.

Creed, P. A., Fallon, T., \& Hood, M. (2009). The relationship between career adaptability, person and situation variables, and career concerns in young adults. Journal of Vocational Behavior, $74,219-229$.

Creed, P. A., Patton, W., \& Bartrum, D. (2002). Multidimensional properties of the LOT-R: Effects of optimism and pessimism on career and well-being related variables in adolescents. Journal of Career Assessment, 10(1), 42-61.

Cüceloğlu, D. (1992). İnsan ve davranışı. İstanbul: Remzi Kitabevi.

Eroğlu, F. (2000). Davranış bilimleri. İstanbul: Beta Yayınları.

Eren, E. (1998). Örgütsel davranış ve yönetim psikolojisi. İstanbul: Beta Yayınları.

Evans, Anthony M. ve William Revelle. (2008). "Survey and behavioral measurements of interpersonal trust." Journal of Research in Personality, 42:1585-159

Furumo, Kimberly, Emmeline de Pillis ve David Green. (2009). "Personality influences trust differently in virtual and face-to-face teams." International Journal Human Resources Development and Management, 9(1): 36-58.

Goldberg, L. R. (1992). "The development of markers for the Big-Five factor structure.” Psychol Assess, 4:26-42.

Hayes, A. F. (2013). An introduction to mediation, moderation, and conditional process analysis: A regression-based approach. New York: Guilford Press.

Hackett, G., ve Byars, A. M. (1996). Social cognitive theory and the career development of African American women. Career Development Quarterly, 44, 322-340.

Hellriegel, D., Slocum, J. W., Woodman, R. W. (1989). Organizational Behavior. St. Paul: West Publishing Company.

Hiraishi, K., Yamagata, S., Shikishima C. ve Ando, J. (2008). "Maintenance of genetic variation in personality through control of mental mechanisms: a test of trust, extraversion and agreeableness." Evolution and Human Behavior, 29: 79-85.

İşcan, Ö. F. ve Sayın, U. (2010). "Örgütsel adalet, iş tatmini ve örgütsel güven arasındaki ilişki." Atatürk Üniversitesi İktisadi ve İdari Bilimler Dergisi, 24(4): 195-216.

Karkoulian, S. ve Osman, Y. (1-2 October 2009). "Prediction of knowledge sharing from big five personality traits via interpersonal trust:an empirical investigation." (177-183). Intellectual Capital, Knowledge Management ve Organisational Learning Konferansinda sunuldu. School of Information Studies, McGill University, Montreal Kanada.

Lent, R. W., Brown, S. D., ve Hackett, G. (1994). Toward a unifying social cognitive theory of career and academic interest, choice and performance (monograph). Journal of Vocational Behavior, 45, 79-122. 
Neuman, W. L. ve Robson, K. (2014). Basics of social research. Toronto: Pearson Canada.

Mooradian, T., Renzl, B. ve Matzler, K. (2006). "Who trusts? personality, trust and knowledge sharing." Management Learning, 37(4): 523-540.

Mount, M. K., Barrick, M. R., \& Stewart, G. L. (1998). "Five-Factor Model of personality and performance in jobs involving interpersonal interactions." Human Performance, 11(2-3): $145-165$.

Özdamar, K.; (1999). Paket programlarla istatistiksel veri analizi 1, Eskişehir: Kaan Kitabevi.

Quinlan, L. M. (2008). Leader Personality Characteristics and Their Effects on Trust in the Organizational Setting. Doctoral Dissertation, Walden University College of Social and Behavioral Sciences, Minneapolis.

Robbins, S. P. ve Judge, T. A. (2012). Organizational Behavior (Örgütsel Davranış), (Erdem, İ. Çev.), Ankara: Nobel Yayın Dağıtım.

Sicora, R. T. (2014). Personality and trust a qualitative study on the personality styles/traits of leaders and employees and the impact on culture of trust within organizations. Doctoral Dissertation, Faculty of the School of Education of the University of St. Thomas, Minnesota.

Savickas, M. L. (2002). Career construction: A developmental theory of vocational behavior. Fourth edition (Ed. D. Brown) Career choice and development (Fourth Edition) (pp. 149-206). San Francisco: Jossey-Bass.

Savickas, M. L. (2005). The theory and practice of career construction. (Ed. S. D. Brown, \& R. W. Lent). Career development and counseling: Putting theory and research to work (pp. 42-70). New York: Wiley.

Somer, O., Korkmaz, M., Tatar, A. (2002). "Beş faktör kișilik envanteri’nin geliştirilmesi: ölçek ve alt ölçeklerin oluşturulması.” Türk Psikoloji Dergisi, 17(49): 21-33.

Tabachnick, B. G. ve Fidell, L. S. (2007). Using multivariate statistics. Boston: Allyn and Bacon.

Tatar, Arkun (2017). "Büyük beş-50 kişilik testinin türkçeye çevirisi ve beş faktör kişilik envanteri kısa formu ile karşılaştırılması." Anadolu Psikiyatri Dergisi 18(1):51-61.

Tokgöz, E. (2012). Örgütsel güven, örgütsel özdeşleşme ve örgütsel vatandaşlık davranışı arasındaki iliş̧ki. Yayınlanmamış Yüksek Lisans Tezi, Balıkesir Üniversitesi Sosyal Bilimler Enstitüsü İşletme Anabilim Dalı, Balıkesir.

Turpçu, E. ve Akyurt, H. (2018). “Turizm eğitimi alan öğrencilerin kariyer streslerinin belirlenmesi: Giresun Üniversitesi lisans öğrencileri üzerine bir araştırma." The Journal of Academic Social Science Studies. 69: 365-380.

Tutar, H. (2015). Mobbing (Nedenleri ve başa çıkma stratejileri: kuramsal yaklaşım). Ankara: Detay Yayıncilik.

Tutar, H. (2016a). Örgütsel davranış. Ankara: Detay Yayıncılık.

Tutar, H. (2016b). Sosyal psikoloji. Ankara: Seçkin Yayıncılık.

Zel, U. (2001). Kişilik ve liderlik: evrensel boyutlarıyla yönetsel açıdan araştırmalar, teoriler ve yorumlar. Ankara: Seçkin Yayıncılık. 